Article

\title{
Signaling Value through Gender Diversity: Evidence from Initial Coin Offerings
}

\author{
Alexander Guzmán ${ }^{1}\left[\right.$, Cristian Pinto-Gutiérrez ${ }^{2, *}$ and María-Andrea Trujillo ${ }^{1}$ (D) \\ 1 CESA School of Business, Bogotá 110311, Colombia; alexander.guzman@cesa.edu.co (A.G.); \\ maria.trujillo@cesa.edu.co (M.-A.T.) \\ 2 Centro de Investigación y Estudios Contables, Faculty of Business and Economics, Universidad de Talca, \\ Talca 3460000, Chile \\ * Correspondence: cristian.pinto@utalca.cl; Tel.: +56-71-220-0200
}

check for updates

Citation: Guzmán, A.;

Pinto-Gutiérrez, C.; Trujillo, M.-A. Signaling Value through Gender Diversity: Evidence from Initial Coin Offerings. Sustainability 2021, 13, 700 https://doi.org/10.3390/su13020700

Received: 7 December 2020 Accepted: 10 January 2021 Published: 13 January 2021

Publisher's Note: MDPI stays neutral with regard to jurisdictional clai$\mathrm{ms}$ in published maps and institutional affiliations.

Copyright: $(\odot 2021$ by the authors. Licensee MDPI, Basel, Switzerland. This article is an open access article distributed under the terms and conditions of the Creative Commons Attribution (CC BY) license (https:// creativecommons.org/licenses/by/ $4.0 /)$.

\begin{abstract}
We analyze women's participation and the effects of team gender diversity on initial coin offering (ICO) success measured by the total funding amount raised in the actual ICO and the project's long-term survival. Using a database featuring 875 initial coin offerings between 2017 and 2019, we find that women are significantly under-represented in ICO projects (on average, only $13 \%$ of team members are women). However, for projects that do have participation of women, we find that team gender diversity increases the total funding raised in the ICO. Moreover, when we separate team members into areas of expertise or roles in the project, we find that the presence of women in critical positions, such as being a founder or having financial or legal responsibilities, significantly reduces the likelihood of long-term coin failure. Our results are consistent with the notion that investors perceive women's participation in leadership positions as a positive signal of desirable organizational practices that will translate into better performance. Our results are also consistent with the idea that having women, who abide by ethical values and are less prone to fraud, reduces the likelihood that informationally opaque ICOs turn out to be scams.
\end{abstract}

Keywords: gender diversity; initial coin offerings; blockchain; entrepreneurship

\section{Introduction}

The United Nations has proposed 17 sustainable development goals to achieve by 2030, including gender equality, sustainable economic growth, and innovation and technological progress. These goals underline the importance of identifying opportunities for progress and promoting the development of individuals to ensure sustainability [1]. One of these opportunities is in Science, Technology, Engineering, and Mathematics (STEM) disciplines, relevant for sustainable development due to their potential for innovation and disruption. However, evidence shows that women are significantly unrepresented in STEM careers. As a consequence, lack of gender diversity is one of the main problems technology companies face today [2], and disruptive new technologies, such as cryptocurrency and blockchain, are highly male-dominated sectors. The gender gap in leadership positions in the technology sector is also severe. For instance, Adams and Kirchmaier (2016) [3] find that board gender diversity is significantly lower for firms in the STEM industries than in the non-STEM sectors. These trends have remained even after empirical evidence has shown that having women in teams improves the decision-making process and assesses a firm's strategic alternatives, stimulates better debates, provides a broader spectrum of strategic options, and fosters collaboration and innovation [4-8]. Increasing the number of women studying and working in STEM fields is, therefore, fundamental towards achieving better solutions to the global challenges $[9,10]$. Furthermore, improving access to external funding for womenled ventures in disruptive technologies is critical for achieving sustainable economic development. 
In this article, we examine the effect that team gender diversity can play in financing entrepreneurial efforts using an Initial Coin Offering (ICO), a new financing instrument designed to raise money by issuing coins or tokens based on smart contracts built on distributed ledger technology (DLT or blockchain) (e.g., [11-19]). In an ICO, entrepreneurial firms create a cryptocurrency and sell it to external investors to raise the funds needed to develop their projects. According to ICOBench.com, one of the most popular rating websites for ICOs, over 5700 ICOs raised more than USD 27 billion between 2017 and 2019 (retrieved from https:/ / icobench.com/on 1 June 2020). This figure represents about 9\% of the value of venture capital investments in the U.S. during the same period (data on venture capital investment in the U.S. is from the PwC/CB Insights MoneyTree ${ }^{\mathrm{TM}}$ Report Q4 2019), which highlights the relevance of ICOs as a source of entrepreneurial finance.

ICOs involve several challenges for both entrepreneurs and investors subscribing to the offerings. In particular, regulatory uncertainty around ICOs and the absence of supervision of such offerings expose both issuers and participants to significant risks [20]. For instance, there is no law on the enforceability of smart contracts or the recourse of investors in case of a loss due to a technological failure of the distributed network. In addition to the severe information asymmetries already present in entrepreneurial companies, characterized by the nonexistence of prior financial information or a performance track record, the lack of disclosure requirements in ICOs impede proper risk assessment of the investment by potential investors [20]. Moreover, there are no specialized intermediaries in the ICO market, such as venture capital firms, to perform appropriate financial due diligence before investing or managing and overseeing the companies investors fund.

These uncertainties and information gaps force investors to consider factors that could signal the quality of the ICO issuers. In particular, investors want to understand the crucial determinants that predict company success and the factors indicating a lower probability of an entrepreneur's opportunistic behavior after receiving financing. Consequently, a growing financial literature has examined the factors determining ICO success. Possible explanations range from information disclosure levels to the commitment of the CEO and the participation of large institutional investors [21-30].

An unexplored aspect that could impact an ICO's success is the participation of women and the level of team gender diversity in an ICO project. ICOs are at the intersection of technology and finance, two sectors with already high gender inequalities. Moreover, most ICO projects are innovative blockchain-based start-ups offering smart contract solutions that require teams' members trained in STEM related disciplines. However, several studies indicate that STEM careers are a male-dominated sector (i.e., [31-33]). This is why cryptocurrency and blockchain technology remains a highly male-dominated industry. For instance, a report by the World Economic Forum (WEF) showed that only 5\% to $7 \%$ of all cryptocurrency users around the world are women [34]. Considering that gender diversity has been proved to increase the potential for innovation [2,5], increasing diversity in teams should be a key issue for blockchain technology companies involved in ICOs.

Furthermore, earlier literature in finance and management has demonstrated the positive impact of having women in leadership positions on a firm's performance [35-39], corporate social responsibility [40,41], corporate fraud [42-45], and innovation [4,5,46,47]. Women also seem to be less prone to overconfidence while being less risk-seeking [48,49] and abiding by ethical values and regulations [50-52], thereby reducing corporate fraud [53-55].

All these positive aspects of gender diversification have made investors take note and put a higher value on firms that have women participating in top management positions, especially in contexts where asymmetric information and adverse selection problems are prevalent. For instance, Welbourne, Cycyota, and Ferrante (2007) [56] showed that women in critical positions are associated with higher first-day returns in initial public offerings (IPOs). The authors argued that team gender diversity is used by investors as a signal of the quality of IPO firms and symbolizes desirable organizational characteristics that increase the likelihood of success. 
In this paper, we analyze the effects of women's participation and team gender diversity in the ICO market, an opaque, unregulated sector of entrepreneurial finance filled with informational gaps and fraud. Using a database featuring 875 initial coins offerings between 2017 and 2019, we show that gender team diversity is positively associated with ICO success measured by the total funding amount raised. This result is consistent with the notion that investors perceive women's participation in ICO teams as a positive signal of necessary organizational practices that result in higher performance. Exploring further elements of team gender diversity, we find that when we separate team members into areas of expertise or roles played in the project, the presence of women in critical positions, such as a founding member or having financial or legal responsibilities, significantly reduces the likelihood of long-term coin failure. In contrast, we do not find that women's positions have a significant effect on the total funding amount raised in the ICO.

Overall, our results indicate that some of the underlying mechanisms in ICOs resemble those found in prior research into corporate and entrepreneurial finance such as IPOs [56] and crowdfunding [57], which is another important entrepreneurial finance market segment for the future [16]. More importantly, our results enable investors and entrepreneurial firms to understand another crucial determinant of ICO success more accurately. In particular, we provide novel evidence for the factors that reduce the uncertainty that investors face when investing in unregulated ICOs and document a previously unknown benefit of women's roles in entrepreneurial companies.

Our study has implications for financial practices, in particular for cryptocurrency investors and entrepreneurial firms conducting ICOs. Participants in the ICO market should be aware of the value of team gender diversity for the entrepreneurial firms facilitating the raising of funds, mitigating risk, and improving the quality and long-term survival rate of the projects.

\section{Literature Review and Hypotheses Development}

A growing financial literature has examined the factors determining the success of and motivations for investing in ICOs. The theoretical underpinnings for most empirical papers examining the overall success of ICOs are motivated by agency-related and moral hazardbased explanations of ICO market outcomes. Consequently, papers typically focus on information disclosure and signaling for ICO success. For instance, Fisch (2019) [11] studied the role of signaling ventures' technological capabilities in ICOs and found that technical white papers and high-quality source codes increase the amount raised by the offering. Roosenboom, van der Kolk, and de Jong (2020) [58] also found evidence that ICOs are more successful in raising funding when they disclose more information to investors. They showed that ICOs raise significantly more funds when they have a higher quality rating from cryptocurrency experts, organize a presale, refrain from offering bonus schemes, have shorter planned token sale durations, and have a larger project team. Roosenboom et al. (2020) [58] also showed that ICOs that disclose more information to investors at the time of the campaign show a higher likelihood of the coin being listed in major cryptocurrency exchanges. Finally, Howell et al. (2020) [13] examined which issuer and ICO characteristics predict successful real outcomes (increasing issuer employment and avoiding enterprise failure). The authors found that disclosure, credible commitment to the project, quality signals, and token liquidity cause higher future utilization.

Some papers have shown that the quality of the CEO and the presence of large institutional investors also determine the success of the ICO. For instance, Momtaz (2020) [59] showed that signals of entrepreneurial quality such as CEO loyalty are positively associated with ICO gross proceeds and other measures of ICO success. Boreiko and Risteski (2020) [60] showed that ICOs that attract large investors raise more funds, attract more contributors, and are more likely to list tokens on major crypto exchange. Meanwhile, Fisch and Momtaz (2020) [17] found that the participation of institutional investors in an ICO is positively associated with the buy-and-hold abnormal returns over the first six months of trading after the token's exchange listing date. A number of articles have also 
examined the underpricing of ICOs (similar to IPOs studies). For instance, Benedetti and Kostovetsky (2021) [61] found evidence of a significant ICO underpricing, with average returns of $179 \%$ from the ICO price to the first day's opening market price. After trading begins, tokens continue to appreciate in price, generating average buy-and-hold abnormal returns of $48 \%$ in the first 30 trading days. However, Momtaz (2019) [62] found that the average ICO underpricing only amounts to $15 \%$, and 4 out of 10 ICOs destroy value on the first trading day. For holding periods between one and twenty-four months, the median ICO depreciates by $30 \%$. Consequently, there are substantial discrepancies among papers examining the underpricing of ICOs.

A relevant and unexplored signaling aspect that could impact an ICO's success is the participation of women and the level of team gender diversity in an ICO project. We expect that investors perceive women's participation in leadership positions as a positive signal of the quality, expected performance, and desirable organizational practices of the ICO firms. This expectation comes from previous empirical research showing the positive impact of having women in leadership positions on firm performance [35-37], corporate social responsibility [40], corporate fraud [42,43], and innovation [4,5,46,47].

Women's participation in leadership positions has also proved to be valuable in the context of severe information asymmetries. For instance, Welbourne et al. (2007) [56] showed a positive relationship between having women on top management teams of initial public offering (IPO) firms and the initial pricing of the offering and subsequent long-term performances. The authors argue that the reasons for women's positive effects on the initial pricing are associated with the signaling implications that having a diverse gender mix sends to the market about positive organizational characteristics that are critical to firms success. Meanwhile, the authors attributed the superior long-term performance to the positive effects of women on improving innovation and problem-solving processes, and the possibility that on average the women on diverse teams are higher performers than men on those same teams.

As in the case of IPO firms, among the main challenges for entrepreneurial firms undertaking an ICO and the investors subscribing to the offering are the extensive information asymmetries and adverse selection problems in ICO firms [63]. We believe that the signal of having a more gender diverse team could mitigate some of the information asymmetries present in the ICO market. We hypothesize that investors notice women on ICO projects and then take that information into consideration when deciding whether or not to invest in an ICO and the amount to be invested. Consequently, we expect ICOs with a higher participation of women to be more successful in raising funding. These arguments lead us to the following hypothesis:

Hypothesis 1: Greater team gender diversity in ICO entrepreneurial firms is positively associated with the total funding raised in the ICO.

The percentage of women in leadership positions could only be considered a signal to investors if it ultimately produces positive future performance. Thus, to understand the effects of gender diversity on the short-term success of an ICO, we also need to examine its impact over the long term. Prior literature has shown that gender diversity leads to significant improvement in the decision-making process and better assessment of the firm's contextual alternatives [8]. Women can also stimulate debate, manage complexity, provide a broader spectrum of strategic options, and foster collaboration and innovation [46]. All of these benefits, the prior literature shows, result in improved long-term firm performance.

A high percentage of women in leadership positions can also improve monitoring activities and reduce the probability of corporate fraud. For instance, Adams and Ferreira (2019) [53] found that women show higher discipline in attending board meetings and that greater gender diversity makes $\mathrm{CEO}$ turnover more sensitive to poor firm performance. The literature also argues that women seem to more closely abide by ethical values and regulations [50-52], thus, leading to the positive effect of women reducing fraud [55,64]. For instance, the Association of Certified Fraud Examiners (ACFE) consistently shows sizeable 
differences between women and men in occupational fraud. In their last report, men committed $72 \%$ of all occupational fraud and also caused larger losses than women [65].

Prior research in psychology and economics has shown that men tend to be more risk-seeking than women [48] and documented gender differences in attitudes toward financial risks [49]. Literature also shows that women are less prone to overconfidence [66] and more likely to value security and take steps to avoid the worst possible outcomes [54]. These results are consistent with financial studies that examine investment decisions by traders [67], financing and investment policies by executives [68], and merger and acquisition decisions by boards of directors [69]. Moreover, Silverman (2003) [70] presents experimental and survey evidence indicating that women are, on average, more patient and better able to delay gratification than men. This literature provides key insights to help explain the benefits of gender diversity in financial decision-making.

Considering the uncertainties and information gaps in the ICO market that allow for the possibility of entrepreneurs' opportunistic behavior after receiving financing, the previously discussed gender differences in ethics and risk-taking, together with the arguments about the benefits of having women in top management positions, are particularly valuable in the ICO context. In particular, we expect differences between women and men to become more relevant in positions that could directly impact fraud [54]. In other business context, Brouthers, Brouthers, and Werner (2000) [71] analyzed the impact of managerial experience on strategic aggressiveness and found that managers with accounting and finance backgrounds pursue more conservative strategies than managers with other managerial experience. In politics, Baskaran et al. (2018) [72] investigated competitive elections to India's state assemblies and found that women legislators are less likely to be criminal and corrupt, more efficacious, and less vulnerable to political opportunism. Consequently, we hypothesize that women in leadership positions, such as CEO, founder, or financial and legal roles increases ICO legitimacy and positively impacts the likelihood of the long-term survival of the project. We posit the following hypothesis:

Hypothesis 2: The presence of women in critical positions such as founder, CEO, and financial or legal responsibilities significantly reduces the likelihood of long-term coin failure.

\section{Methods and Data}

\subsection{Methodology}

We use a multivariate setting to examine the impact of women's participation and team gender diversity on ICO success. First, we regress the natural logarithm of total gross proceeds from the ICO on a set of variables measuring team gender diversity and control variables using the following ordinary least squares (OLS) specification:

$$
\begin{aligned}
& \text { Ln(ICO gross proceeds })_{i} \\
& \qquad \begin{array}{l}
=\alpha+\beta_{1} * \text { Gender diversity } i+\beta_{2} * \text { Woman position }_{i}+\gamma^{\prime} X_{i} \\
+
\end{array}
\end{aligned}
$$

Our main dependent variable is Ln (ICO gross proceeds) $)_{i}$, which is the natural logarithm of total gross proceeds from the ICO in U.S. dollars. Depending on the regression model we use, the variable Gender diversity represents either the total number of female team members, the percentage of female team members, or the Blau index for gender diversity [73]. The variable Woman position represents women's participation in critical roles (CEO, founder, financial, and legal). Given the frequency of women in marketing positions and the importance of developers and blockchain engineers for ICO projects, we also include marketing, development, and blockchain in this definition of critical roles.

The vector $X_{i}$ contains the control variables. First, we control for expert ratings of the ICO management team, its vision, and its product [59]. As there are no regulations on ICO structure, we control also for the use of the technical standard ERC20 that contains a list of rules for developers creating smart contracts on the Ethereum blockchain. We 
also include a dummy for projects that accept payment in fiat currency. Prior literature has shown that more extended fundraising periods likely indicate the project is having trouble raising the desired amount, which is a negative signal to potential investors [14]. Therefore, we control for the ICO duration. We also control for pre-ICO offers and bonuses for early investors (pre-ICO bonus). These schemes could lower the fundraising amount because early adopters can buy tokens at a lower price before the ICO. Finally, the ICO phenomenon depends on the geographic distribution and location of the projects [74]. We control for the number of countries excluded from the ICO and for whether the start-up is located in the U.S. Finally, we include year $\left(T_{i}\right)$ fixed-effects in all regressions. We do not control for industry-fixed effects for different reasons. First, ICObench provides different industrial sectors for each project, making it difficult to have an accurate classification of the coin offerings by industry. In addition, investors should perceive ICOs as having similar industrial risk, due to the use of smart contracts built on distributed ledger technology to raise funds and the high average rate of failure in the ICOs.

We also examine how women's participation and gender diversity affect the likelihood that an ICO coin will ultimately die. Our dependent variable equals 1 if ICO $i$ has a dead coin at the end of June 2020 and zero otherwise. We employ a logistic regression model with the following specification:

$$
\begin{aligned}
\operatorname{Pr}\left[\text { Dead } \operatorname{coin}_{i}=\right. & 1] \\
& =\alpha+\beta_{1} * \text { Gender diversity } y_{i}+\beta_{2} * \text { Woman position }_{i}+\gamma^{\prime} X_{i} \\
& +T_{i}+\epsilon_{i},
\end{aligned}
$$

where we define an ICO as having a dead coin if it meets any of the following conditions: (i) the token symbol or coin name appears listed in deadcoins.com (deadcoins.com is a community forum where contributors can post information about dead or dying coins. The website classifies dead coins into four categories: (a) failed projects, (b) hacked coins, (c) scams, and (d) parodies, (ii) the coin name appears listed in coinopcy.com (coinopcy.com is also a contribution-based forum, where contributors may receive a bounty of up to $0.1 \mathrm{ETH}$ (Ethereum) if the site administrators verify the information. According to coinopcy.com, a dead coin refers to a cryptocurrency that has been abandoned, used as a scam, had its website down, has no nodes, has wallet issues, does not have social updates, has low volume, or its developers have walked away from the project), and (iii) the token is not listed in CoinMarketCap as of June 2020 (since we used a sample of ICOs that ended on 31 December 2019, we allowed for a period of at least six months for ICOs to list their tokens. According to Momtaz (2020) [14], once a project has raised funds, it takes 93 days on average from the end of the ICO until the first token exchange listing). The variables Gender Diversity, Woman Position, and vector $X_{i}$ are all defined as in Equation (1), except that we include one additional control variable for the natural logarithm of the ICO's gross proceeds in U.S. dollars. We also include year-fixed $\left(T_{i}\right)$ effects.

\subsection{Data}

Our primary source of ICO data is ICObench, an ICO rating platform that provides a comprehensive list of coin offerings. ICObench provides the most thorough and highest quality information on ICO campaigns [58]. Moreover, due to its comprehensive coverage, ICObench has been used in several previous studies $[14,17,58,59,74,75]$. The first ICO appeared in 2013 (MasterCoin). However, ICOBench only includes ICO data starting from 2015. The few projects published in 2015 and 2016 have incomplete information concerning our key variables and controls, in particular, information regarding team members. For this reason, we restricted our sample to ICOs from 2017 to 2019. This sample period includes the two most active years (i.e., 2017 and 2018) in the ICO market both in terms of number of projects and funds raised. To measure coin failure, we collect data from deadcoins.com, coinopcy.com, and CoinMarketCap.

We start with a list of 4133 ICO-ended offers between January 2017 and December 2019. From this total, we identify almost 45 thousand people participating on these ICO 
teams. Tables 1 and 2 describe the main characteristics of ICO team members in terms of their gender and position in the company. Table 1 presents role and gender distributions across all ICOs. Descriptive statistics show that ICO teams on average are dominated by men with women's participation at only $14 \%$. This proportion is even lower when we consider critical positions such as founders $(6 \%)$, CEOs ( $4 \%)$, developers $(8 \%)$, and blockchain jobs (4\%). We believe that this gender disparity in ICOs is only an extension of a trend that has existed for decades in technology industries caused by the shortage of women in STEM fields. Our data also shows that women are under-represented in ICOs top decision-making and STEM-related positions. These figures are consistent with prior studies documenting the low participation of woman in cryptocurrencies and blockchain industries (e.g., [76,77]).

Table 1. Number of people involved in ICOs by gender and critical positions.

\begin{tabular}{|c|c|c|c|c|}
\hline & \multicolumn{2}{|c|}{ All Team Members } & \multicolumn{2}{|c|}{ Excluding Advisors } \\
\hline & Number & $\%$ & Number & $\%$ \\
\hline Total people involved in ICOs & 45,917 & & 33,348 & \\
\hline Women involved in ICOs & 6451 & $14 \%$ & 5362 & $16 \%$ \\
\hline Men involved in ICOs & 39,466 & $86 \%$ & 27,986 & $84 \%$ \\
\hline Total founders & 4614 & & 4614 & \\
\hline Women founders & 288 & $6 \%$ & 288 & $6 \%$ \\
\hline Men founders & 4326 & $94 \%$ & 4326 & $94 \%$ \\
\hline Total CEOs & 3001 & & 3001 & \\
\hline Women CEOs & 134 & $4 \%$ & 134 & $4 \%$ \\
\hline Men CEOs & 2867 & $96 \%$ & 2867 & $96 \%$ \\
\hline Total of people in financial or legal positions & 3462 & & 2071 & \\
\hline Women in financial or legal positions & 637 & $18 \%$ & 461 & $22 \%$ \\
\hline Men in financial or legal positions & 2825 & $82 \%$ & 1610 & $78 \%$ \\
\hline Total of people in marketing positions & 2750 & & 2157 & \\
\hline Women in marketing positions & 773 & $28 \%$ & 693 & $32 \%$ \\
\hline Men in marketing positions & 1977 & $72 \%$ & 1464 & $68 \%$ \\
\hline Total of people in developer positions & 7135 & & 6702 & \\
\hline Women in developer positions & 582 & $8 \%$ & 544 & $8 \%$ \\
\hline Men in developer positions & 6553 & $92 \%$ & 6158 & $92 \%$ \\
\hline Total of people in blockchain positions & 2756 & & 1751 & \\
\hline Women in blockchain positions & 124 & $4 \%$ & 73 & $4 \%$ \\
\hline Men in blockchain positions & 2632 & $96 \%$ & 1678 & $96 \%$ \\
\hline
\end{tabular}

Note: This table presents the number and percentage of people involved in ICOs, categorized by gender and critical positions, including and excluding advisors. The sample is comprised of 4133 initial coin offerings (ICOs) between 2017 and 2019.

Table 2 shows the 15 most common words mentioned in the role descriptions for ICO team members, classified by gender and type of involvement (management team or advisor). In this table, we see the differences in roles filled by men and women. For instance, the most common positions for men include developer, $\mathrm{CEO}$, and founder. While for women, some of the most common roles include marketing, designer, and community manager. Even more, consider the case of a CEO. The position appears at the top of the list for men, while it shows up at the bottom for women. 
Table 2. The 15 most common words mentioned in role descriptions for ICO team members.

\begin{tabular}{|c|c|c|c|c|c|c|c|}
\hline \multicolumn{4}{|c|}{ All Team Members } & \multicolumn{4}{|c|}{ Excluding Advisors } \\
\hline \multicolumn{2}{|c|}{ Men } & \multicolumn{2}{|c|}{ Women } & \multicolumn{2}{|c|}{ Men } & \multicolumn{2}{|c|}{ Women } \\
\hline Role & $\%$ & Role & $\%$ & Role & $\%$ & Role & $\%$ \\
\hline Advisor & $6.1 \%$ & Manager & $6.3 \%$ & Developer & $5.5 \%$ & Manager & $7.7 \%$ \\
\hline Developer & $3.8 \%$ & Marketing & $4.4 \%$ & CEO & $3.2 \%$ & Marketing & $4.9 \%$ \\
\hline CEO & $2.7 \%$ & Advisor & $3.4 \%$ & Manager & $3.1 \%$ & Director & $2.4 \%$ \\
\hline Blockchain & $2.4 \%$ & Director & $2.0 \%$ & Co-founder & $2.9 \%$ & Head & $2.3 \%$ \\
\hline Co-founder & $2.2 \%$ & Head & $1.9 \%$ & Chief & $2.5 \%$ & Designer & $2.2 \%$ \\
\hline Manager & $2.2 \%$ & Community & $1.9 \%$ & Blockchain & $2.3 \%$ & Community & $2.2 \%$ \\
\hline Chief & $1.9 \%$ & Business & $1.8 \%$ & Founder & $2.1 \%$ & Developer & $2.0 \%$ \\
\hline Founder & $1.8 \%$ & Designer & $1.8 \%$ & Officer & $2.1 \%$ & Business & $1.9 \%$ \\
\hline Marketing & $1.8 \%$ & Developer & $1.6 \%$ & Engineer & $2.0 \%$ & Development & $1.5 \%$ \\
\hline Director & $1.6 \%$ & Development & $1.4 \%$ & Marketing & $2.0 \%$ & PR & $1.5 \%$ \\
\hline Development & $1.5 \%$ & PR & $1.4 \%$ & Director & $1.9 \%$ & Chief & $1.5 \%$ \\
\hline Officer & $1.5 \%$ & Chief & $1.3 \%$ & Development & $1.9 \%$ & Officer & $1.5 \%$ \\
\hline Engineer & $1.4 \%$ & Officer & $1.2 \%$ & CTO & $1.8 \%$ & Project & $1.2 \%$ \\
\hline Business & $1.3 \%$ & Project & $1.1 \%$ & Lead & $1.7 \%$ & Co-founder & $1.2 \%$ \\
\hline CTO & $1.3 \%$ & Media & $1.0 \%$ & Head & $1.7 \%$ & Media & $1.2 \%$ \\
\hline Head & $1.2 \%$ & Co-founder & $1.0 \%$ & Business & $1.3 \%$ & Specialist & $1.0 \%$ \\
\hline Lead & $1.2 \%$ & Legal & $1.0 \%$ & Software & $1.2 \%$ & Relations & $1.0 \%$ \\
\hline Senior & $0.9 \%$ & CEO & $1.0 \%$ & Senior & $1.2 \%$ & Social & $1.0 \%$ \\
\hline Software & $0.9 \%$ & Relations & $0.9 \%$ & Community & $0.9 \%$ & Lead & $0.9 \%$ \\
\hline Expert & $0.7 \%$ & Specialist & $0.9 \%$ & Project & $0.9 \%$ & CEO & $0.9 \%$ \\
\hline
\end{tabular}

Note: This table presents the most words (and their frequencies) mentioned in role descriptions for ICO team members, categorized by gender, including and excluding advisors. The sample is comprised of 4133 initial coin offerings (ICOs) between 2017 and 2019.

For the empirical analysis that follows, we remove all ICOs with incomplete information concerning our key variables and controls. After this filter, we are able to identify 875 ICOs ended between 2017 and 2019. Table 3 presents descriptive statistics for the final sample including the number of ICOs, the average gross proceeds, the average number of team members, and the percentage of woman team members, categorized by year and industry, respectively. We find in Panel A that the highest number of ICOs took place in 2017, which coincides with the year of rapid increase in Bitcoin price. The average ICO size has decreased over time with around \$16 million in 2017 and \$4.5 million in 2019. The average total number of team members is 16 , and the average proportion of women team members is around $12 \%$ in most years. In terms of dead ICOs, projects launched in 2018 have the highest rate of failure. In Panel B, we observe that banking is the industry with the largest number of ICOs, while internet and media industries have the most funds raised. The largest participation of women is in the charity and internet industries. In terms of dead ICOs, the industries with the most failures are legal (77.8\%) and smart contracts (77.3\%).

Table 4 provides descriptive statistics for the full final sample of ICOs. The results show that the average natural logarithm of gross proceeds is 15.42 (the average, in U.S. dollars, for ICO proceeds is $\$ 11.1$ million), while about $66 \%$ of ICOs are dead in 2020 according to our definition. The average size of the team is 17 people, of which $13 \%$ are women. Seven percent of all ICOs have a woman founder or co-founder. Only $3 \%$ of CEOs are women. Sixteen percent of ICOs have a woman in a financial or legal position, and $21 \%$ of projects have a woman in a marketing role. Fifteen percent of all ICOs have a woman developer, and only $3 \%$ of ICOs have a woman with a blockchain-related position. 
Table 3. Distribution of ICOs by year and industry.

\begin{tabular}{|c|c|c|c|c|c|}
\hline \multicolumn{6}{|c|}{ Panel A: Distribution of ICOs by year } \\
\hline Year & Number of ICOs & Gross Proceeds (\$000) & \% Dead Coins & Number of Members & \% Women \\
\hline 2017 & 177 & $15,969.8$ & $54.8 \%$ & 14.5 & $11.1 \%$ \\
\hline 2018 & 567 & $11,099.0$ & $68.4 \%$ & 17.5 & $13.1 \%$ \\
\hline 2019 & 131 & 4510.7 & $67.9 \%$ & 15.3 & $12.2 \%$ \\
\hline \multicolumn{6}{|c|}{ Panel B: Distribution of ICOs by industry } \\
\hline Industry & Number of ICOs & Gross Proceeds (\$000) & \% Dead Coins & Number of Members & \% Women \\
\hline Banking & 72 & $21,742.7$ & $61.1 \%$ & 15.5 & $13.2 \%$ \\
\hline Investment & 54 & $10,820.3$ & $68.5 \%$ & 14.3 & $9.7 \%$ \\
\hline Cryptocurrency & 50 & $12,826.8$ & $66.0 \%$ & 15.0 & $10.7 \%$ \\
\hline Big data & 50 & 9693.3 & $72.0 \%$ & 17.9 & $13.1 \%$ \\
\hline Media & 48 & $22,972.8$ & $60.4 \%$ & 18.5 & $14.1 \%$ \\
\hline Platform & 48 & 7930.4 & $45.8 \%$ & 17.3 & $12.6 \%$ \\
\hline Retail & 43 & 8855.0 & $72.1 \%$ & 18.8 & $13.8 \%$ \\
\hline Software & 41 & 8709.5 & $73.2 \%$ & 15.7 & $10.3 \%$ \\
\hline Business services & 40 & $10,642.3$ & $62.5 \%$ & 15.3 & $9.7 \%$ \\
\hline Communication & 38 & 8575.9 & $68.4 \%$ & 15.2 & $9.9 \%$ \\
\hline Entertainment & 32 & 6284.8 & $62.5 \%$ & 15.2 & $10.6 \%$ \\
\hline Education & 31 & 5674.9 & $67.7 \%$ & 17.0 & $11.7 \%$ \\
\hline Artificial intelligence & 30 & 8259.9 & $70.0 \%$ & 18.8 & $14.9 \%$ \\
\hline Infrastructure & 28 & 8207.7 & $57.1 \%$ & 16.6 & $12.7 \%$ \\
\hline Health & 25 & $10,747.3$ & $76.0 \%$ & 19.1 & $16.1 \%$ \\
\hline Sports & 24 & 3545.2 & $58.3 \%$ & 14.3 & $13.5 \%$ \\
\hline Electronics & 23 & $10,946.2$ & $65.2 \%$ & 18.7 & $14.1 \%$ \\
\hline Tourism & 23 & 4098.1 & $69.6 \%$ & 16.2 & $15.8 \%$ \\
\hline Smart contracts & 22 & 5545.9 & $77.3 \%$ & 16.2 & $11.0 \%$ \\
\hline Internet & 21 & $23,388.2$ & $61.9 \%$ & 16.1 & $16.6 \%$ \\
\hline Virtual reality & 21 & $10,575.8$ & $71.4 \%$ & 18.4 & $13.9 \%$ \\
\hline Real estate & 20 & 6789.5 & $75.0 \%$ & 17.1 & $14.4 \%$ \\
\hline Energy & 19 & $12,294.9$ & $68.4 \%$ & 16.8 & $12.9 \%$ \\
\hline Manufacturing & 19 & $12,232.4$ & $73.7 \%$ & 14.1 & $11.6 \%$ \\
\hline Casino and gambling & 19 & $11,278.9$ & $57.9 \%$ & 15.7 & $10.0 \%$ \\
\hline Legal & 18 & 5671.4 & $77.8 \%$ & 15.7 & $14.3 \%$ \\
\hline Charity & 11 & $11,154.8$ & $45.5 \%$ & 22.6 & $18.5 \%$ \\
\hline Others & 5 & 6310.0 & $40.0 \%$ & 13.0 & $9.7 \%$ \\
\hline
\end{tabular}

Note: This table presents gross proceeds (in thousands of dollars), percentage of dead coins, number of team members (including advisors), and percentage of female team members (including advisors), categorized by year (Panel A) and industry (Panel B). The sample is comprised of 875 initial coin offerings (ICOs) between 2017 and 2019.

Table 4. Descriptive statistics of key variables.

\begin{tabular}{|c|c|c|c|c|c|c|c|c|}
\hline Variable & $\mathbf{N}$ & Mean & Median & SD & Min & Max & P25 & P75 \\
\hline \multicolumn{9}{|l|}{ Dependent variables: } \\
\hline ICO gross proceeds $(\ln )$ & 875 & 15.18 & 15.42 & 1.71 & 5.24 & 20.17 & 14.22 & 16.40 \\
\hline Dead coin (dummy) & 875 & 0.66 & 1.00 & 0.48 & 0.00 & 1.00 & 0.00 & 1.00 \\
\hline \multicolumn{9}{|l|}{ ICO gender diversity variables: } \\
\hline $\mathrm{N}$ of team members & 875 & 16.52 & 15.00 & 8.47 & 1.00 & 75.00 & 11.00 & 20.00 \\
\hline $\mathrm{N}$ of women team members & 875 & 2.20 & 2.00 & 2.25 & 0.00 & 21.00 & 1.00 & 3.00 \\
\hline$\%$ of women team members & 875 & 0.13 & 0.11 & 0.10 & 0.00 & 0.60 & 0.05 & 0.19 \\
\hline Gender Blau index & 875 & 0.20 & 0.20 & 0.14 & 0.00 & 0.50 & 0.10 & 0.30 \\
\hline \multicolumn{9}{|l|}{ ICO women position variables: } \\
\hline Woman founder (dummy) & 875 & 0.07 & 0.00 & 0.25 & 0.00 & 1.00 & 0.00 & 0.00 \\
\hline Woman CEO (dummy) & 875 & 0.03 & 0.00 & 0.17 & 0.00 & 1.00 & 0.00 & 0.00 \\
\hline $\begin{array}{l}\text { Woman financial or legal } \\
\text { position (dummy) }\end{array}$ & 875 & 0.16 & 0.00 & 0.37 & 0.00 & 1.00 & 0.00 & 0.00 \\
\hline
\end{tabular}


Table 4. Cont.

\begin{tabular}{|c|c|c|c|c|c|c|c|c|}
\hline Variable & $\mathbf{N}$ & Mean & Median & SD & Min & Max & $\mathbf{P} 25$ & P75 \\
\hline $\begin{array}{l}\text { Woman marketing position } \\
\text { (dummy) }\end{array}$ & 875 & 0.21 & 0.00 & 0.40 & 0.00 & 1.00 & 0.00 & 0.00 \\
\hline $\begin{array}{l}\text { Woman developer position } \\
\text { (dummy) }\end{array}$ & 875 & 0.15 & 0.00 & 0.36 & 0.00 & 1.00 & 0.00 & 0.00 \\
\hline $\begin{array}{l}\text { Woman blockchain position } \\
\text { (dummy) }\end{array}$ & 875 & 0.04 & 0.00 & 0.19 & 0.00 & 1.00 & 0.00 & 0.00 \\
\hline \multicolumn{9}{|l|}{ Control variables: } \\
\hline Team rating & 875 & 3.85 & 4.00 & 0.90 & 1.00 & 5.00 & 3.40 & 4.50 \\
\hline Vision rating & 875 & 3.82 & 4.00 & 0.87 & 1.00 & 5.00 & 3.40 & 4.40 \\
\hline Product rating & 875 & 3.57 & 3.70 & 0.89 & 1.00 & 5.00 & 3.00 & 4.10 \\
\hline ERC20 (dummy) & 875 & 0.92 & 1.00 & 0.28 & 0.00 & 1.00 & 1.00 & 1.00 \\
\hline Fiat accepted (dummy) & 875 & 0.20 & 0.00 & 0.40 & 0.00 & 1.00 & 0.00 & 0.00 \\
\hline ICO duration (days) & 875 & 59.84 & 36.00 & 63.00 & 0.00 & 670.00 & 28.00 & 77.00 \\
\hline $\mathrm{N}$ country restrictions & 875 & 2.49 & 1.00 & 7.58 & 0.00 & 123.00 & 0.00 & 2.00 \\
\hline U.S. restriction (dummy) & 875 & 0.41 & 0.00 & 0.49 & 0.00 & 1.00 & 0.00 & 1.00 \\
\hline Pre-ICO (dummy) & 875 & 0.63 & 1.00 & 0.48 & 0.00 & 1.00 & 0.00 & 1.00 \\
\hline Bonus scheme (dummy) & 875 & 0.56 & 1.00 & 0.50 & 0.00 & 1.00 & 0.00 & 1.00 \\
\hline U.S. location (dummy) & 875 & 0.09 & 0.00 & 0.29 & 0.00 & 1.00 & 0.00 & 0.00 \\
\hline
\end{tabular}

Note: This table reports summary statistics for the dependent, independent, and control variables used in this study. The sample is comprised of 875 initial coin offerings (ICOs) between 2017 and 2019. See Appendix A for variable definitions.

\section{Results}

We begin by discussing the univariate relationship between the mean values of our key dependent variables (the natural logarithms ICO gross proceeds and the dummy variable dead coin that it equals if the coin is dead in 2020) and several variables representing women's participation in the ICOs and team gender diversity. The ICO projects are split into "high" and "low" groups for continuous variables based on the lowest and highest quintiles of the variable distribution, or into "yes" and "no" groups for subsamples based on dummy variables. In Table 5, we report the means of gross proceeds (ln) for ICOs for these two groups. The mean gross proceeds for the high and low subsample of total numbers of women participating in the ICOs is 14.86 and 15.70, respectively. The difference between the mean gross proceeds for the two groups is statistically significant. We find a similar pattern for subsamples based on the percentage of women team members and the Blau index for team gender diversity. These results are consistent with the prediction that when women's participation and gender diversity is high, ICOs are more successful in raising money. We also perform a difference-in-means test between subsamples for the percentage of dead coins. In Table 5, we see that ICOs with more women on their teams, and especially ICOs with a woman founder, experience significantly lower rates of failure. Overall, the univariate relationship between ICO success and women's participation and gender diversity measured in different ways is consistent with our hypotheses.

Next, we perform a multivariate analysis to test the relationship between gender diversity and ICO success. Table 6 presents the parameters estimated from OLS regressions for the amount of money raised by the ICO on several proxies for gender diversity and control variables. Columns 1 and 2 report the results when we use the total number of women involved in the project. Columns 3 and 4 present the results for the percentage of women team members. Finally, columns 5 and 6 show the results for gender diversity using the Blau index. Having women on the teams and gender diversity have a statistically significant and positive effect on the amount raised by the ICO across all models. Consequently, Hypothesis 1 is supported. 
Table 5. Univariate analysis for gross proceeds (in natural logarithm) and dead coins, categorized by female participation.

\begin{tabular}{|c|c|c|c|c|}
\hline Variable & Attribute & Low or No & High or Yes & High or Yes-Low or No \\
\hline \multirow{3}{*}{ Total N women } & Mean proceeds $(\ln )$ & 14.86 & 15.70 & $0.85^{* * *}$ \\
\hline & Mean dead coins & 0.67 & 0.56 & $-0.10 *$ \\
\hline & $\mathrm{N}$ & 186.00 & 110.00 & \\
\hline \multirow{3}{*}{$\%$ of women } & Mean proceeds $(\ln )$ & 14.86 & 15.27 & $0.42 * *$ \\
\hline & Mean dead coins & 0.67 & 0.66 & 0.00 \\
\hline & $\mathrm{N}$ & 186.00 & 170.00 & \\
\hline \multirow{3}{*}{ Gender Blau index } & Mean proceeds (ln) & 14.86 & 15.27 & $0.42 * *$ \\
\hline & Mean dead coins & 0.67 & 0.66 & 0.00 \\
\hline & $\mathrm{N}$ & 186.00 & 170.00 & \\
\hline \multirow{3}{*}{ Founder woman } & Mean proceeds (ln) & 15.17 & 15.33 & 0.16 \\
\hline & Mean dead coins & 0.67 & 0.51 & $-0.16^{* *}$ \\
\hline & $\mathrm{N}$ & 814.00 & 61.00 & \\
\hline \multirow{3}{*}{ CEO woman } & Mean proceeds $(\ln )$ & 15.18 & 15.24 & 0.06 \\
\hline & Mean dead coins & 0.66 & 0.68 & 0.02 \\
\hline & $\mathrm{N}$ & 850.00 & 25.00 & \\
\hline \multirow{3}{*}{$\begin{array}{l}\text { At least } 1 \text { woman in legal or } \\
\text { finance position }\end{array}$} & Mean proceeds $(\ln )$ & 15.20 & 15.05 & -0.15 \\
\hline & Mean dead coins & 0.67 & 0.61 & -0.06 \\
\hline & $\mathrm{N}$ & 732.00 & 143.00 & \\
\hline \multirow{3}{*}{$\begin{array}{l}\text { At least } 1 \text { woman in } \\
\text { marketing position }\end{array}$} & Mean proceeds $(\ln )$ & 15.15 & 15.27 & 0.12 \\
\hline & Mean dead coins & 0.66 & 0.63 & -0.03 \\
\hline & $\mathrm{N}$ & 695.00 & 180.00 & \\
\hline \multirow{3}{*}{$\begin{array}{l}\text { At least } 1 \text { woman in } \\
\text { developer position }\end{array}$} & Mean proceeds $(\ln )$ & 15.14 & 15.41 & $0.28 *$ \\
\hline & Mean dead coins & 0.66 & 0.65 & -0.01 \\
\hline & $\mathrm{N}$ & 744.00 & 131.00 & \\
\hline \multirow{3}{*}{$\begin{array}{l}\text { At least } 1 \text { woman in } \\
\text { blockchain position }\end{array}$} & Mean proceeds $(\ln )$ & 15.16 & 15.70 & $0.54 *$ \\
\hline & Mean dead coins & 0.65 & 0.71 & 0.05 \\
\hline & $\mathrm{N}$ & 841.00 & 34.00 & \\
\hline
\end{tabular}

Note: This table shows the univariate results regarding the relationship between different proxies for gender diversity and ICO success, measured by the natural logarithm of the actual amount raised in the ICO and the percentage of failed coins. The ICO projects are split into "high" and "low" groups for continuous variables based on the lowest and highest quintiles of the variable distribution or into "yes" and "no" groups for subsamples based on dummy variables. The sample is comprised of 875 initial coin offerings (ICOs) between 2017 and 2019 . ***, **, and * indicate the mean difference between groups is significantly different from zero at the $1 \%, 5 \%$, and $10 \%$ significance level, respectively.

Table 6. Ordinary least squares (OLS) regression ICO gross proceeds.

\begin{tabular}{|c|c|c|c|c|c|c|}
\hline Dep: ICO Gross Proceeds (ln) & (1) & (2) & (3) & (4) & (5) & (6) \\
\hline Women team members (\#) & $\begin{array}{c}0.0662 \text { ** } \\
(2.3658)\end{array}$ & $\begin{array}{c}0.0593 * * \\
(2.0088)\end{array}$ & & & & \\
\hline Women team members (\%) & & & $\begin{array}{c}1.5686^{* * *} \\
(2.9629)\end{array}$ & $\begin{array}{l}1.3098^{* *} \\
(2.3003)\end{array}$ & & \\
\hline Women Blau index & & & & & $\begin{array}{c}1.1369^{* * *} \\
(2.7590)\end{array}$ & $\begin{array}{c}0.9257^{* *} \\
(2.0617)\end{array}$ \\
\hline Woman Founder & $\begin{array}{c}0.0587 \\
(0.2784)\end{array}$ & $\begin{array}{c}0.0617 \\
(0.2895)\end{array}$ & $\begin{array}{c}0.0689 \\
(0.3184)\end{array}$ & $\begin{array}{c}0.0713 \\
(0.3257)\end{array}$ & $\begin{array}{c}0.0745 \\
(0.3428)\end{array}$ & $\begin{array}{c}0.0767 \\
(0.3496)\end{array}$ \\
\hline Woman CEO & $\begin{array}{l}-0.1429 \\
(0.4803)\end{array}$ & $\begin{array}{l}-0.1337 \\
(0.4385)\end{array}$ & $\begin{array}{l}-0.1969 \\
(0.6495)\end{array}$ & $\begin{array}{l}-0.1707 \\
(0.5462)\end{array}$ & $\begin{array}{l}-0.1954 \\
(0.6427)\end{array}$ & $\begin{array}{l}-0.1666 \\
(0.5309)\end{array}$ \\
\hline Women financial or legal & $\begin{array}{c}-0.2900 * \\
(1.8712)\end{array}$ & $\begin{array}{c}-0.2804 * \\
(1.8064)\end{array}$ & $\begin{array}{l}-0.2375 \\
(1.5530)\end{array}$ & $\begin{array}{l}-0.2285 \\
(1.4949)\end{array}$ & $\begin{array}{l}-0.2426 \\
(1.5749)\end{array}$ & $\begin{array}{l}-0.2313 \\
(1.5029)\end{array}$ \\
\hline Women marketing & & $\begin{array}{c}0.0139 \\
(0.1044)\end{array}$ & & $\begin{array}{c}0.0404 \\
(0.2992)\end{array}$ & & $\begin{array}{c}0.0444 \\
(0.3262)\end{array}$ \\
\hline Women developer & & $\begin{array}{c}0.0836 \\
(0.5686)\end{array}$ & & $\begin{array}{c}0.1526 \\
(1.0471)\end{array}$ & & $\begin{array}{c}0.1604 \\
(1.0937)\end{array}$ \\
\hline Women blockchain & & 0.2960 & & 0.3618 & & 0.3523 \\
\hline
\end{tabular}


Table 6. Cont

\begin{tabular}{|c|c|c|c|c|c|c|}
\hline Dep: ICO Gross Proceeds (ln) & (1) & (2) & (3) & (4) & (5) & (6) \\
\hline \multirow{3}{*}{ Total team members (\#) } & & $(1.1133)$ & & $(1.4011)$ & & $(1.3556)$ \\
\hline & 0.0160 & 0.0154 & & & & \\
\hline & $(1.6269)$ & $(1.5667)$ & & & & \\
\hline \multirow[t]{2}{*}{ Team rating } & 0.2214 * & 0.2241 * & $0.3075^{* *}$ & $0.3017^{* *}$ & $0.3015^{* *}$ & $0.2964 * *$ \\
\hline & $(1.7771)$ & $(1.7985)$ & $(2.4770)$ & $(2.4334)$ & $(2.4391)$ & $(2.4010)$ \\
\hline \multirow[t]{2}{*}{ Vision rating } & -0.0423 & -0.0367 & -0.0625 & -0.0544 & -0.0623 & -0.0545 \\
\hline & $(0.3128)$ & $(0.2699)$ & $(0.4579)$ & $(0.3978)$ & $(0.4569)$ & $(0.3986)$ \\
\hline \multirow[t]{2}{*}{ Product rating } & 0.0309 & 0.0251 & 0.0170 & 0.0119 & 0.0138 & 0.0096 \\
\hline & $(0.2457)$ & $(0.1989)$ & $(0.1360)$ & $(0.0945)$ & $(0.1104)$ & $(0.0758)$ \\
\hline \multirow[t]{2}{*}{ ERC20 } & -0.0550 & -0.0525 & -0.0623 & -0.0571 & -0.0581 & -0.0535 \\
\hline & $(0.3093)$ & $(0.2956)$ & $(0.3438)$ & $(0.3154)$ & $(0.3212)$ & $(0.2958)$ \\
\hline \multirow[t]{2}{*}{ Fiat } & $0.4239^{* * *}$ & $0.4227^{* * *}$ & $0.4611^{* * *}$ & $0.4534^{* * *}$ & $0.4625^{* * *}$ & $0.4540^{* * *}$ \\
\hline & $(3.1600)$ & $(3.1300)$ & $(3.4441)$ & $(3.3656)$ & $(3.4495)$ & $(3.3633)$ \\
\hline \multirow[t]{2}{*}{ ICO duration } & $-0.0036^{* * *}$ & $-0.0037^{* * *}$ & $-0.0036^{* * *}$ & $-0.0037^{* * *}$ & $-0.0036^{* * *}$ & $-0.0037^{* * *}$ \\
\hline & (3.7096) & (3.7883) & (3.4491) & $(3.5944)$ & $(3.4389)$ & $(3.5880)$ \\
\hline \multirow[t]{2}{*}{$\mathrm{N}$ of country restrictions } & 0.0076 & 0.0073 & 0.0106 & 0.0100 & 0.0107 & 0.0100 \\
\hline & $(1.1822)$ & $(1.1385)$ & $(1.5449)$ & $(1.4650)$ & $(1.5738)$ & $(1.4881)$ \\
\hline \multirow[t]{2}{*}{ U.S. restriction } & -0.0354 & -0.0424 & -0.0504 & -0.0577 & -0.0528 & -0.0595 \\
\hline & $(0.2969)$ & $(0.3535)$ & $(0.4197)$ & $(0.4780)$ & $(0.4391)$ & $(0.4925)$ \\
\hline \multirow[t]{2}{*}{ Pre-ICO offer } & 0.2234 * & 0.2234 * & $0.2446^{*}$ & $0.2435 *$ & $0.2430 *$ & $0.2423 *$ \\
\hline & $(1.8024)$ & (1.8050) & (1.9409) & (1.9363) & $(1.9275)$ & $(1.9259)$ \\
\hline \multirow[t]{2}{*}{ Pre-ICO bonus } & $-0.3380^{* * *}$ & $-0.3338^{* * *}$ & $-0.3008^{* * *}$ & $-0.3005^{* * *}$ & $-0.3016^{* * *}$ & $-0.3016^{* * *}$ \\
\hline & $(2.9583)$ & (2.9115) & $(2.6176)$ & $(2.6082)$ & $(2.6241)$ & $(2.6170)$ \\
\hline \multirow[t]{2}{*}{ U.S. location } & 0.2997 & 0.2899 & 0.3098 & 0.2970 & 0.3066 & 0.2945 \\
\hline & $(1.4444)$ & $(1.3901)$ & $(1.4942)$ & $(1.4268)$ & $(1.4774)$ & $(1.4137)$ \\
\hline \multirow[t]{2}{*}{ Constant } & $14.7930^{* * *}$ & $14.7833^{* * *}$ & $14.7482 * * *$ & $14.7530 * * *$ & $14.7521 * * *$ & $14.7597^{* * *}$ \\
\hline & $(40.5131)$ & $(40.4672)$ & $(39.4928)$ & $(39.4144)$ & $(39.4754)$ & $(39.3695)$ \\
\hline Year-fixed effects & Yes & Yes & Yes & Yes & Yes & Yes \\
\hline Number of observations & 875 & 875 & 875 & 875 & 875 & 875 \\
\hline $\mathrm{R} 2$ & 0.1570 & 0.1586 & 0.1467 & 0.1497 & 0.1461 & 0.1492 \\
\hline
\end{tabular}

Note: This table presents the parameter estimates from ordinary least squared regressions, with robust standard errors, for the actual amount raised in the ICO (in natural logarithm). The key independent variables are the gender diversity proxies. All control variables are defined in Appendix A. $t$ values (in parentheses) are computed with robust standard errors. ${ }^{* * *},{ }^{* *}$, and ${ }^{*}$ indicate that the coefficient is significantly different from zero at the $1 \%, 5 \%$, and $10 \%$ levels, respectively.

Several control variables in Table 6 across all models show meaningful results that respond to expectations and prior literature. For instance, the amount of money raised is positively related to the quality of the team (rated by ICOBench experts), accepting fiat currency from investors, and having a pre-ICO offer period. Meanwhile, the amount of money raised is negatively related to the duration of the ICO campaign and discounts offered during the pre-ICO period.

Finally, we analyze the long-term effects of having women in key positions. Table 6 shows the logistic regressions and the estimation results when we regress the probability of coin failure (dead coin) on women's participation in critical positions and the control variables. Gender diversity measures have a statistically insignificant effect on the probability of being dead. However, when we consider the role of women in the project, we find that having a female founder and a woman acting in a task related to financial and legal positions, there is a negative and statistically significant effect on the probability of coin failure. Consequently, our results partially support Hypothesis 2: The likelihood of experiencing project failure (dead coin) is negatively related to the degree of women's involvement in top management positions that could directly impact fraud.

Several control variables also show meaningful results in Table 7 across all models. Consistent with our arguments in Hypothesis 1, the probability of a dead coin is negatively related to the amount raised by the ICO. Results show that the duration of the ICO cam- 
paign and the existence of a pre-ICO period are positively associated with the probability of long-term coin failure.

Table 7. Logit regressions for the likelihood of the coin being dead.

\begin{tabular}{|c|c|c|c|c|c|c|}
\hline Dep: Pr. (Dead Coin = 1) & (1) & (2) & (3) & (4) & (5) & (6) \\
\hline Women team members (\#) & $\begin{array}{c}0.0180 \\
(0.3970)\end{array}$ & $\begin{array}{c}0.0347 \\
(0.6923)\end{array}$ & & & & \\
\hline Women team members (\%) & & & $\begin{array}{c}0.6083 \\
(0.7572)\end{array}$ & $\begin{array}{c}1.0955 \\
(1.1953)\end{array}$ & & \\
\hline Women Blau index & & & & & $\begin{array}{c}0.4189 \\
(0.7119)\end{array}$ & $\begin{array}{c}0.7730 \\
(1.1651)\end{array}$ \\
\hline Woman Founder & $\begin{array}{c}-0.7249 * * \\
(2.3191)\end{array}$ & $\begin{array}{c}-0.7196^{* *} \\
(2.2900)\end{array}$ & $\begin{array}{c}-0.7559 * * \\
(2.4210)\end{array}$ & $\begin{array}{c}-0.7555^{* *} \\
(2.4076)\end{array}$ & $\begin{array}{c}-0.7519 * * \\
(2.4118)\end{array}$ & $\begin{array}{c}-0.7496^{* *} \\
(2.3920)\end{array}$ \\
\hline Woman CEO & $\begin{array}{c}0.5142 \\
(1.0824)\end{array}$ & $\begin{array}{c}0.4672 \\
(0.9743)\end{array}$ & $\begin{array}{c}0.5035 \\
(1.0490)\end{array}$ & $\begin{array}{c}0.4264 \\
(0.8801)\end{array}$ & $\begin{array}{c}0.5061 \\
(1.0564)\end{array}$ & $\begin{array}{c}0.4298 \\
(0.8904)\end{array}$ \\
\hline Women financial or legal & $\begin{array}{c}-0.4259 * * \\
(2.0494)\end{array}$ & $\begin{array}{c}-0.4270 * * \\
(2.0389)\end{array}$ & $\begin{array}{c}-0.4869 * * \\
(2.3510)\end{array}$ & $\begin{array}{c}-0.4922^{* *} \\
(2.3574)\end{array}$ & $\begin{array}{c}-0.4872 * * \\
(2.3381)\end{array}$ & $\begin{array}{c}-0.4950 \text { ** } \\
(2.3570)\end{array}$ \\
\hline Women marketing & & $\begin{array}{l}-0.1959 \\
(0.9447)\end{array}$ & & $\begin{array}{l}-0.2683 \\
(1.2748)\end{array}$ & & $\begin{array}{l}-0.2649 \\
(1.2556)\end{array}$ \\
\hline Women developer & & $\begin{array}{l}-0.0700 \\
(0.2972)\end{array}$ & & $\begin{array}{l}-0.1400 \\
(0.6008)\end{array}$ & & $\begin{array}{l}-0.1340 \\
(0.5781)\end{array}$ \\
\hline Women blockchain & & $\begin{array}{c}0.3832 \\
(0.8711)\end{array}$ & & $\begin{array}{c}0.3176 \\
(0.7290)\end{array}$ & & $\begin{array}{c}0.3107 \\
(0.7140)\end{array}$ \\
\hline Total team members (\#) & $\begin{array}{l}-0.0139 \\
(0.9974)\end{array}$ & $\begin{array}{l}-0.0161 \\
(1.1366)\end{array}$ & & & & \\
\hline Gross proceeds (ln) & $\begin{array}{c}-0.2369^{* * *} \\
(4.3777)\end{array}$ & $\begin{aligned}- & 0.2402^{* * *} \\
& (4.4247)\end{aligned}$ & $\begin{array}{c}-0.2454^{* * *} \\
(4.5537)\end{array}$ & $\begin{array}{c}-0.2483^{* * *} \\
(4.5971)\end{array}$ & $\begin{array}{c}-0.2450^{* * *} \\
(4.5450)\end{array}$ & $\begin{aligned}- & 0.2479 * * * \\
& (4.5831)\end{aligned}$ \\
\hline Team rating & $\begin{array}{l}-0.0127 \\
(0.0795)\end{array}$ & $\begin{array}{l}-0.0015 \\
(0.0093)\end{array}$ & $\begin{array}{l}-0.0513 \\
(0.3320)\end{array}$ & $\begin{array}{l}-0.0355 \\
(0.2298)\end{array}$ & $\begin{array}{l}-0.0534 \\
(0.3457)\end{array}$ & $\begin{array}{l}-0.0400 \\
(0.2584)\end{array}$ \\
\hline Vision rating & $\begin{array}{l}-0.0188 \\
(0.1136)\end{array}$ & $\begin{array}{l}-0.0057 \\
(0.0342)\end{array}$ & $\begin{array}{l}-0.0056 \\
(0.0338)\end{array}$ & $\begin{array}{c}0.0092 \\
(0.0559)\end{array}$ & $\begin{array}{c}-0.0059 \\
(0.0358)\end{array}$ & $\begin{array}{c}0.0084 \\
(0.0510)\end{array}$ \\
\hline Product rating & $\begin{array}{c}-0.1548 \\
(0.9330)\end{array}$ & $\begin{array}{c}-0.1683 \\
(1.0130)\end{array}$ & $\begin{array}{l}-0.1518 \\
(0.9215)\end{array}$ & $\begin{array}{l}-0.1696 \\
(1.0301)\end{array}$ & $\begin{array}{l}-0.1526 \\
(0.9268)\end{array}$ & $\begin{array}{c}-0.1708 \\
(1.0370)\end{array}$ \\
\hline ERC20 & $\begin{array}{c}0.4249 \\
(1.5232)\end{array}$ & $\begin{array}{c}0.4217 \\
(1.4978)\end{array}$ & $\begin{array}{c}0.4304 \\
(1.5396)\end{array}$ & $\begin{array}{c}0.4243 \\
(1.5079)\end{array}$ & $\begin{array}{c}0.4321 \\
(1.5451)\end{array}$ & $\begin{array}{c}0.4275 \\
(1.5185)\end{array}$ \\
\hline Fiat & $\begin{array}{l}0.3421 * \\
(1.7302)\end{array}$ & $\begin{array}{l}0.3514^{*} \\
(1.7696)\end{array}$ & $\begin{array}{l}0.3338^{*} \\
(1.6874)\end{array}$ & $\begin{array}{l}0.3502 * \\
(1.7614)\end{array}$ & $\begin{array}{l}0.3344^{*} \\
(1.6912)\end{array}$ & $\begin{array}{l}0.3509^{*} \\
(1.7670)\end{array}$ \\
\hline ICO duration & $\begin{array}{c}0.0090^{* * * *} \\
(4.0841)\end{array}$ & $\begin{array}{c}0.0090^{* * * *} \\
(4.1272)\end{array}$ & $\begin{array}{c}0.0090^{* * *} \\
(4.0313)\end{array}$ & $\begin{array}{c}0.0089^{* * * *} \\
(4.0863)\end{array}$ & $\begin{array}{c}0.0090^{* * *} \\
(4.0334)\end{array}$ & $\begin{array}{c}0.0090^{* * * *} \\
(4.0858)\end{array}$ \\
\hline $\mathrm{N}$ of country restrictions & $\begin{array}{c}0.0018 \\
(0.1836)\end{array}$ & $\begin{array}{c}0.0016 \\
(0.1604)\end{array}$ & $\begin{array}{c}0.0003 \\
(0.0356)\end{array}$ & $\begin{array}{c}0.0004 \\
(0.0412)\end{array}$ & $\begin{array}{c}0.0004 \\
(0.0386)\end{array}$ & $\begin{array}{c}0.0005 \\
(0.0466)\end{array}$ \\
\hline U.S. restriction & $\begin{array}{c}0.1187 \\
(0.6617)\end{array}$ & $\begin{array}{c}0.1055 \\
(0.5831)\end{array}$ & $\begin{array}{c}0.1315 \\
(0.7335)\end{array}$ & $\begin{array}{c}0.1193 \\
(0.6592)\end{array}$ & $\begin{array}{c}0.1302 \\
(0.7266)\end{array}$ & $\begin{array}{c}0.1173 \\
(0.6487)\end{array}$ \\
\hline Pre-ICO offer & $\begin{array}{c}0.1464 \\
(0.8756)\end{array}$ & $\begin{array}{c}0.1532 \\
(0.9156)\end{array}$ & $\begin{array}{c}0.1249 \\
(0.7520)\end{array}$ & $\begin{array}{c}0.1278 \\
(0.7694)\end{array}$ & $\begin{array}{c}0.1246 \\
(0.7503)\end{array}$ & $\begin{array}{c}0.1269 \\
(0.7643)\end{array}$ \\
\hline Pre-ICO bonus & $\begin{array}{c}0.4021^{* *} \\
(2.5306)\end{array}$ & $\begin{array}{c}0.4188^{* * * *} \\
(2.6172)\end{array}$ & $\begin{array}{l}0.3768^{* *} \\
(2.4094)\end{array}$ & $\begin{array}{c}0.3981^{* *} \\
(2.5224)\end{array}$ & $\begin{array}{c}0.3769 * * \\
(2.4102)\end{array}$ & $\begin{array}{c}0.3977 * * \\
(2.5209)\end{array}$ \\
\hline U.S. location & $\begin{array}{l}-0.3027 \\
(1.1899)\end{array}$ & $\begin{array}{l}-0.3310 \\
(1.2949)\end{array}$ & $\begin{array}{l}-0.3039 \\
(1.2005)\end{array}$ & $\begin{array}{l}-0.3324 \\
(1.3101)\end{array}$ & $\begin{array}{l}-0.3055 \\
(1.2064)\end{array}$ & $\begin{array}{l}-0.3347 \\
(1.3174)\end{array}$ \\
\hline Constant & $\begin{array}{c}3.7883 * * * \\
(3.9103)\end{array}$ & $\begin{array}{c}3.8267^{* * * *} \\
(3.9413)\end{array}$ & $\begin{array}{c}3.7918^{* * *} \\
(3.9428)\end{array}$ & $\begin{array}{c}3.7854^{* * * *} \\
(3.9316)\end{array}$ & $\begin{array}{c}3.7897^{* * * *} \\
(3.9403)\end{array}$ & $\begin{array}{c}3.7829 * * * \\
(3.9271)\end{array}$ \\
\hline Year-fixed effects & Yes & Yes & Yes & Yes & Yes & Yes \\
\hline Number of observations & 875 & 875 & 875 & 875 & 875 & 875 \\
\hline Pseudo R2 & 0.1053 & 0.1069 & 0.1046 & 0.1069 & 0.1045 & 0.1067 \\
\hline
\end{tabular}

Note: This table presents the parameter estimates from logistic regressions, with robust standard errors, for the likelihood of coin failure as of June 2020. The key independent variables are the gender diversity proxies. All control variables are defined in Appendix A. $t$ values (in parentheses) are computed with robust standard errors. ${ }^{* * *},{ }^{* *}$, and ${ }^{*}$ indicate that the coefficient is significantly different from zero at the $1 \%, 5 \%$, and $10 \%$ levels, respectively. 


\section{Discussion}

We now discuss the results and how they can be interpreted from the perspective of previous studies and of the working hypotheses.

Despite the large number of investors and projects financed using ICOs in recent years and the expanding literature examining the determinants of ICO success, the effects of gender diversity on ICO markets have received scant attention in the literature compared to other signaling factors, such as information disclosure, technological capabilities, the commitment of the CEO, and the participation of large institutional investors. This study examines the essential features of women's involvement in ICO projects that have not been previously analyzed.

In particular, we show that gender team diversity is positively associated with ICO success measured by the total funding amount raised and that the presence of women in critical positions, such as a founding member or having financial or legal responsibilities, significantly reduces the likelihood of long-term coin failure. This is consistent with the findings of Welbourne et al. (2007) [56] in the context of initial public offerings (IPOs). Using data from IPO firms in the U.S., the authors show that women have a positive association with firms' short-term performance measured by Tobin's $Q$, three-year stock price growth, and growth in earnings per share. They argue that the positive effect of women on performance could be explained by more innovation and better problem-solving processes associated with diverse top management teams.

Our results are also in line with previous studies showing the positive effect of gender diversity on leadership positions and firms' financial performance in complex and innovative contexts. According to Francoeur et al. (2008) [47], firms operating in complex environments generate positive and significant abnormal returns when they have a high proportion of women officers. Moreover, Dezsö and Ross (2012) [46] found that female representation in top management improves firm performance, but only when a firm's strategy is focused on innovation.

We believe that the ICO market represents a proper setting to test the hypotheses concerning gender diversification and financial performance. In more regulated contexts, female participation has shown benefits in reducing corporate fraud and bad managerial decisions. For instance, Gupta et al. (2020) [44] show that firms with female CFOs have a lower likelihood of financial misreporting than comparable firms with male CFOs, especially when governance is weak. Similarly, Krishnan and Parsons (2008) show that men and women behave differently when it comes to earnings quality. These authors show that earnings quality is positively associated with gender diversity in senior management. Previous research also highlights the benefits of having women involved in corporate decision-making. For instance, Huang and Kisgen (2013) [68] found that acquisitions made by female executives have higher announcement returns compared with those made by firms with male executives and that announcement returns for debt offerings are higher when the firm has a female executive. According to these authors, their evidence suggests that men exhibit relative overconfidence in important corporate decisions compared with women. In the case of the unregulated ICO market, the benefits of having women on the team are even more pivotal. Our results show that the presence of women in critical positions such as founder and financial or legal roles significantly reduces the likelihood of long-term coin failure, including scams, hacked coins, or projects that failed to list the coin on major exchanges.

Women have already repeatedly demonstrated their STEM abilities, having contributed, for example, to increasing firms' value and corporate innovation (e.g., [3,5]). In other areas of knowledge, women have been instrumental in progress on the prevention of cholera and cancer and expanding our understanding of brain development and stem cells, among further advancements [31]. Our results provide yet another reason for ensuring women have equal access to STEM careers. Our analysis clearly reveals the crucial role of gender diversity in the success of cryptocurrencies and blockchain projects. Moreover, 
having access to innovative financing instruments may help women-led ventures overcome some biases that affected traditional formal funding alternatives such as venture capital.

\section{Concluding Remarks}

In this paper, we analyze the effects of team gender diversity in the ICO market, an opaque sector of entrepreneurial finance filled with informational gaps and fraud. Using a database of 875 initial coins offerings between 2017 and 2019, we show that team gender diversity is positively associated with ICO success measured by the total funding amount raised. Exploring further effects of gender diversity, when we separate team members into areas of expertise or roles in the project, we find that the presence of women in critical positions, such as being a founder or having financial or legal responsibilities, significantly reduces the probability of long-term coin failure of ICOs. Our findings are consistent with the notion that investors perceive women's participation in leadership positions as a positive signal of desirable organizational practices that will translate into better performance. Our results are also consistent with the idea that woman more effectively manage entrepreneurial firms and having women, who abide by ethical values and are less prone to fraud, reduces the likelihood that informationally opaque ICOs turn out to be scams.

Our results help explain another critical determinant of ICO success. In particular, we provide novel evidence on how women's participation reduces investors' uncertainty when investing in unregulated ICOs and document a previously unknown effect of gender diversity in entrepreneurial finance and the technology sector. Our study has implications for financial practices, specifically for cryptocurrency investors and entrepreneurial firms conducting ICOs. Participants in the ICO market should be aware of team gender diversity's value to facilitate an entrepreneurial firm's fund-raising, risk mitigation, improved project quality, and long-term survival rates.

Several important questions need to be addressed. For example, we exclusively focus on the signaling value that gender diversity has on ICO markets. We argue that gender diversity signals positive organizational characteristics and differences in ethics and risktaking that increases the probability of success of female-led ICOs. However, we do not directly measure organizational characteristics of ICOs or examine the ethical attitudes or risk-taking behavior of ICO leaders. Future research should provide evidence regarding the materialization of these expectations. One limitation of our study is associated with the newness of the ICO market. Although we can proxy for the failure of ICOs allowing for at least six months after the offering, some firms still fail after this time frame. Moreover, in addition to the ultimate failure of the token, we would like to examine long-term financial and nonfinancial performance for ICO firms. This examination will allow us to further address the importance of this new financing instrument and the value of gender diversity on the ICO market.

Despite these limitations, overall, the results are consistent with our intuition that the contributions of having women are even more significant in markets with high uncertainties and informational gaps. More importantly, this article sheds light on the degree that team gender diversity can play a particularly vital role in financing entrepreneurial efforts using new financing instruments when formal financial markets are weak, and entrepreneurs face strong external financial constraints.

Author Contributions: Conceptualization, C.P.-G., A.G., and M.-A.T.; methodology, C.P.-G., A.G., and M.-A.T.; software, C.P.-G., A.G., and M.-A.T.; validation, C.P.-G., A.G., and M.-A.T.; formal analysis, C.P.-G., A.G., and M.-A.T.; investigation, C.P.-G., A.G., and M.-A.T.; resources, C.P.-G., A.G., and M.-A.T.; data curation, C.P.-G., A.G., and M.-A.T.; writing-original draft preparation, C.P.-G., A.G., and M.-A.T.; writing-review and editing, C.P.-G., A.G., and M.-A.T. All authors have read and agreed to the published version of the manuscript.

Funding: This research received no external funding.

Institutional Review Board Statement: Not applicable.

Informed Consent Statement: Not applicable. 
Data Availability Statement: The data presented in this study are available on request from the corresponding author.

Conflicts of Interest: The authors declare no conflict of interest.

\section{Appendix A}

Table A1 defines dependent, independent, and control variables used in this study.

Table A1. Definitions of variables.

\begin{tabular}{|c|c|}
\hline Variable Name & Definition \\
\hline ICO proceeds $(\ln )$ & Natural logarithm of the total funding amount raised by the initial coin offering (ICO) in USD. \\
\hline Dead coin & $\begin{array}{l}\text { A dummy variable that equals } 1 \text { if the coin is dead as of June } 2020 \text { and zero otherwise. We define } \\
\text { an ICO with a dead coin if it meets any of the following conditions: (i) the token symbol or coin } \\
\text { name appears listed in deadcoins.com, (ii) the coin name appears listed in coinopcy.com, or (iii) } \\
\text { the token is not listed in CoinMarketCap as of June } 2020 \text {. }\end{array}$ \\
\hline Total team members (\#) & The total number of ICO team members (including advisors). \\
\hline Women team members (\#) & The total number of female ICO team members (including advisors). \\
\hline Women team members (\%) & Women team members (\#)/Total team members (\#) \\
\hline Women Blau index & Defined as $\left(1-p^{2}-(1-p)^{2}\right)$, where $p$ is the percentage of women team members (Blau, 1977). \\
\hline Woman founder & A dummy variable that equals 1 if the founder is a woman and zero otherwise. \\
\hline Woman CEO & A dummy variable that equals 1 if the CEO is a woman and zero otherwise. \\
\hline Women financial or legal & $\begin{array}{l}\text { A dummy variable that equals } 1 \text { if there is at least one woman in a financial or legal role on the } \\
\text { ICO team (including advisors) and zero otherwise. }\end{array}$ \\
\hline Women marketing & $\begin{array}{l}\text { A dummy variable that equals } 1 \text { if there is at least one woman in a marketing role within the ICO } \\
\text { team (including advisors) and zero otherwise. }\end{array}$ \\
\hline Women developer & $\begin{array}{l}\text { A dummy variable that equals } 1 \text { if there is at least one woman in a developer role within the ICO } \\
\text { team (including advisors) and zero otherwise. }\end{array}$ \\
\hline Women blockchain & $\begin{array}{l}\text { A dummy variable that equals } 1 \text { if there is at least one woman in a blockchain role within the ICO } \\
\text { team (including advisors) and zero otherwise. }\end{array}$ \\
\hline Team rating & $\begin{array}{l}\text { A rating based on surveys among cryptocurrency experts, which takes into account the quality of } \\
\text { the management team and the experience of external consultants advising the project. The rating } \\
\text { scale ranges from } 0 \text { (weak) to } 5 \text { (strong). }\end{array}$ \\
\hline Vision rating & $\begin{array}{c}\text { A rating based on surveys among cryptocurrency experts, which takes into account the vision of } \\
\text { the project. The rating scale ranges from } 0 \text { (weak) to } 5 \text { (strong). }\end{array}$ \\
\hline Product rating & $\begin{array}{c}\text { A rating based on surveys among cryptocurrency experts, which takes into account the product } \\
\text { maturity level. The rating scale ranges from } 0 \text { (weak) to } 5 \text { (strong). }\end{array}$ \\
\hline ERC20 & $\begin{array}{l}\text { A dummy variable that equals } 1 \text { if the ICO tokens were created under the ERC20 standard and } \\
\text { zero otherwise. The ERC } 20 \text { is a technical standard that contains a list of rules for developers } \\
\text { creating smart contracts on the Ethereum blockchain. }\end{array}$ \\
\hline Fiat & $\begin{array}{c}\text { A dummy variable that equals } 1 \text { if the project accepted fiat currencies during the ICO and } \\
\text { zero otherwise. }\end{array}$ \\
\hline ICO duration & The duration of the ICO campaign in days. \\
\hline $\begin{array}{l}\text { Number of country } \\
\text { restrictions }\end{array}$ & The number of countries that were excluded from the ICO. \\
\hline U.S. restriction & $\begin{array}{c}\text { A dummy variable that equals } 1 \text { if U.S. investors were not admitted to take part in the ICO and } \\
\text { zero otherwise. }\end{array}$ \\
\hline Pre-ICO offer & A dummy variable that equals 1 if a pre-ICO took place before the actual ICO and zero otherwise. \\
\hline Pre-ICO bonus & $\begin{array}{c}\text { A dummy variable that equals } 1 \text { if the founders offered price discounts to earlier investors and } \\
\text { zero otherwise. }\end{array}$ \\
\hline U.S. location & A dummy variable that equals 1 if the start-up is headquartered in the U.S. and zero otherwise. \\
\hline
\end{tabular}




\section{References}

1. Di Fabio, A. The psychology of sustainability and sustainable development for well-being in organizations. Front. Psychol. 2017, 8, 1534. [CrossRef]

2. Botella, C.; Rueda, S.; López-Iñesta, E.; Marzal, P. Gender diversity in STEM disciplines: A multiple factor problem. Entropy 2019, 21, 30. [CrossRef] [PubMed]

3. Adams, R.B.; Kirchmaier, T. Women on boards in finance and STEM industries. Am. Econ. Rev. 2016, 106, 277-281. [CrossRef]

4. Díaz-García, C.; González-Moreno, A.; Saez-Martinez, F.J. Gender diversity within R\&D teams: Its impact on radicalness of innovation. Innovation 2013, 15, 149-160.

5. Griffin, D.; Li, K.; Xu, T. Board gender diversity and corporate innovation: International evidence. J. Financ. Quant. Anal. 2019, 1-32. [CrossRef]

6. Nielsen, S.; Huse, M. The contribution of women on boards of directors: Going beyond the surface. Corp. Gov. 2010, 18, 136-148. [CrossRef]

7. Nielsen, S.; Huse, M. Women directors' contribution to board decision-making and strategic involvement: The role of equality perception. Eur. Manag. Rev. 2010, 7, 16-29. [CrossRef]

8. Zimmerman, M.A. The influence of top management team heterogeneity on the capital raised through an initial public offering. Entrep. Theory Pract. 2008, 32, 391-414. [CrossRef]

9. López-Iñesta, E.; Botella, C.; Rueda, S.; Forte, A.; Marzal, P. Towards breaking the gender gap in science, technology, engineering and mathematics. IEEE Rev. Iberoam. Tecnol. Aprendiz. 2020, 15, 233-241. [CrossRef]

10. Benavent, X.; de Ves, E.; Forte, A.; Botella-Mascarell, C.; López-Iñesta, E.; Rueda, S.; Roger, S.; Perez, J.; Portalés, C.; Dura, E.; et al. Girls4STEM: Gender diversity in STEM for a sustainable future. Sustainability 2020, 12, 6051. [CrossRef]

11. Fisch, C. Initial coin offerings (ICOs) to finance new ventures. J. Bus. Ventur. 2019, 34, 1-22. [CrossRef]

12. Ahluwalia, S.; Mahto, R.V.; Guerrero, M. Blockchain technology and startup financing: A transaction cost economics perspective. Technol. Forecast. Soc. Chang. 2020, 151, 119854. [CrossRef]

13. Howell, S.; Niessner, M.; Yermack, D. Initial coin offerings: Financing growth with cryptocurrency token sales. Rev. Financ. Stud. 2020, 33, 3925-3974. [CrossRef]

14. Momtaz, P.P. Initial coin offerings. PLOS ONE 2020, 15, e0233018. [CrossRef]

15. Adhami, S.; Giudici, G.; Martinazzi, S. Why do businesses go crypto? An empirical analysis of initial coin offerings. J. Econ. Bus. 2018, 100, 64-75. [CrossRef]

16. Block, J.H.; Groh, A.; Hornuf, L.; Vanacker, T.; Vismara, S. The entrepreneurial finance markets of the future: A comparison of crowdfunding and initial coin offerings. Small Bus. Econ. 2020, 1-18. [CrossRef]

17. Fisch, C.; Momtaz, P.P. Institutional investors and post-ICO performance: An empirical analysis of investor returns in initial coin offerings (ICOs). J. Corp. Financ. 2020, 64, 101679. [CrossRef]

18. Gächter, I.; Gächter, M. Success factors in ICOs: Individual firm characteristics or lucky timing? Financ. Res. Lett. 2020. [CrossRef]

19. Guzmán, A.; Pinto-Gutiérrez, C.; Trujillo, M.A. Attention to Global Warming and the Success of Environmental Initial Coin Offerings: Empirical Evidence. Sustainability 2020, 12, 9885. [CrossRef]

20. OECD. Initial Coin Offerings (ICOs) for SME Financing. 2019. Available online: www.oecd.org/finance/initial-coin-offeringsfor-sme-financing.htm (accessed on 1 December 2020).

21. Kher, R.; Terjesen, S.; Liu, C. Blockchain, Bitcoin, and ICOs: A review and research agenda. Small Bus. Econ. 2020. [CrossRef]

22. Masiak, C.; Block, J.H.; Masiak, T.; Neuenkirch, M.; Pielen, K.N. Initial coin offerings (ICOs): Market cycles and relationship with bitcoin and ether. Small Bus. Econ. 2019, 55, 1113-1130. [CrossRef]

23. Ribeiro-Soriano, D.; Piñeiro-Chousa, J.; López-Cabarcos, M. What factors drive returns on initial coin offerings? Technol. Forecast. Soc. Chang. 2020, 153, 119915.

24. Giudici, G.; Adhami, S. The impact of governance signals on ICO fundraising success. J. Ind. Bus. Econ. 2019, 46, 283-312. [CrossRef]

25. Fisch, C.; Masiak, C.; Vismara, S.; Block, J. Motives and profiles of ICO investors. J. Bus. Res. 2020. [CrossRef]

26. Sharma, Z.; Zhu, Y. Platform building in initial coin offering market: Empirical evidence. Pac.-Basin Financ. J. 2020, 61, 101318. [CrossRef]

27. Samieifar, S.; Baur, D. Read me If you can! An analysis of ICO white papers. Financ. Res. Lett. 2020. [CrossRef]

28. Drobetz, W.; Momtaz, P.P.; Schröder, H. Investor sentiment and initial coin offerings. J. Altern. Invest. 2019, 21, 41-55. [CrossRef]

29. An, J.; Duan, T.; Hou, W.; Xu, X. Initial coin offerings and entrepreneurial finance: The role of founders' characteristics. J. Altern. Invest. 2019, 21, 26-40. [CrossRef]

30. Giudici, G.; Giuffra, G.; Martinazzi, S. The role of advisors' centrality in the success of Initial Coin Offerings. J. Econ. Bus. 2020, 112, 105932. [CrossRef]

31. UNESCO. Cracking the Code: Girls' and Women's Education in Science, Technology, Engineering and Mathematics (STEM). 2017. Available online: http:/ / unesdoc.unesco.org/images/0025/002534/253479e.pdf (accessed on 1 December 2020).

32. She Figures 2018. Gender Equality in Research and Innovation in the European Union: Doctoral Graduates. 2018. Available online: https:/ / op.europa.eu/en/publication-detail/- / publication/9540ffa1-4478-11e9-a8ed-01aa75ed71a1 (accessed on 1 December 2020). 
33. PwC UK. Women in Tech, Time to Close the Gender Gap. 2017. Available online: https:/ /www.pwc.co.uk/women-in-technology / women-in-tech-report.pdf (accessed on 1 December 2020).

34. Tans, G. Why It's Vital We Close the Tech Gender Gap. In Proceedings of the World Economic Forum, Davos-Klosters, Switzerland, 23-26 January 2018; Available online: https:/ / www.weforum.org/agenda/2018/01/close-the-tech-gender-gap-gillian-tans / (accessed on 1 December 2020).

35. Carter, D.A.; Simkins, B.J.; Simpson, W.G. Corporate governance, board diversity, and firm value. Financ. Rev. 2003, 38, 33-53. [CrossRef]

36. Campbell, K.; Mínguez-Vera, A. Gender diversity in the boardroom and firm financial performance. J. Bus. Ethics 2008, 83, 435-451. [CrossRef]

37. Erhardt, N.L.; Werbel, J.D.; Shrader, C.B. Board of director diversity and firm financial performance. Corp. Gov. Int. Rev. 2003, 11, 102-111. [CrossRef]

38. González, M.; Guzmán, A.; Pablo, E.; Trujillo, M.A. Does gender really matter in the boardroom? Evidence from closely held family firms. Rev. Manag. Sci. 2020, 14, 221-267. [CrossRef]

39. Nguyen, T.H.N.; Ntim, C.G.; Malagila, J.K. Women on corporate boards and corporate financial and non-financial performance: A systematic literature review and future research agenda. Int. Rev. Financ. Anal. 2020, 71, 101554. [CrossRef]

40. Dang, R.; Houanti, L.H.; Sahut, J.M.; Simioni, M. Do women on corporate boards influence corporate social performance? A control function approach. Financ. Res. Lett. 2020, 101645. [CrossRef]

41. Byron, K.; Post, C. Women on boards of directors and corporate social performance: A meta-analysis. Corp. Gov. Int. Rev. 2016, 24, 428-442. [CrossRef]

42. Kyaw, K.; Olugbode, M.; Petracci, B. Does gender diverse board mean less earnings management? Financ. Res. Lett. 2015, 14, 135-141. [CrossRef]

43. Liao, J.; Smith, D.; Liu, X. Female CFOs and accounting fraud: Evidence from China. Pac.-Basin Financ. J. 2019, 53, 449-463. [CrossRef]

44. Gupta, V.K.; Mortal, S.; Chakrabarty, B.; Guo, X.; Turban, D.B. CFO gender and financial statement irregularities. Acad. Manag. J. 2020, 63, 802-831. [CrossRef]

45. Krishnan, G.V.; Parsons, L.M. Getting to the bottom line: An exploration of gender and earnings quality. J. Bus. Ethics 2008, 78, 65-76. [CrossRef]

46. Dezsö, C.L.; Ross, D.G. Does female representation in top management improve firm performance? A panel data investigation. Strateg. Manag. J. 2012, 33, 1072-1089. [CrossRef]

47. Francoeur, C.; Labelle, R.; Sinclair-Desgagné, B. Gender diversity in corporate governance and top management. J. Bus. Ethics 2008, 81, 83-95. [CrossRef]

48. Arch, E.C. Risk-taking: A motivational basis for sex differences. Psychol. Rep. 1993, 73, 3-11. [CrossRef]

49. Croson, R.; Gneezy, U. Gender differences in preferences. J. Econ. Lit. 2009, 47, 448-474. [CrossRef]

50. Franke, G.R.; Crown, D.F.; Spake, D.F. Gender differences in ethical perceptions of business practices: A social role theory perspective. J. Appl. Psychol. 1997, 82, 920-934. [CrossRef]

51. Kennedy, J.A.; Kray, L.J.; Ku, G. A social-cognitive approach to understanding gender differences in negotiator ethics: The role of moral identity. Organ. Behav. Hum. Decis. Process. 2017, 138, 28-44. [CrossRef]

52. Lee, M.; Pitesa, M.; Pillutla, M.M.; Thau, S. Male immorality: An evolutionary account of sex differences in unethical negotiation behavior. Acad. Manag. J. 2017, 60, 2014-2044. [CrossRef]

53. Adams, R.B.; Ferreira, D. Women in the boardroom and their impact on governance and performance. J. Financ. Econ. 2019, 94, 291-309. [CrossRef]

54. Cumming, D.; Leung, T.Y.; Rui, O. Gender diversity and securities fraud. Acad. Manag. J. 2015, 58, 1572-1593. [CrossRef]

55. Barua, A.; Davidson, L.F.; Rama, D.V.; Thiruvadi, S. CFO gender and accruals quality. Account. Horizons 2010, 24, 25-39. [CrossRef]

56. Welbourne, T.M.; Cycyota, C.S.; Ferrante, C.J. Wall Street reaction to women in IPOs: An examination of gender diversity in top management teams. Gr. Organ. Manag. 2007, 32, 524-547. [CrossRef]

57. Malaga, R.; Mamonov, S.; Rosenblum, J. Gender difference in equity crowdfunding: An exploratory analysis. Int. J. Gend. Entrep. 2018, 10, 332-343. [CrossRef]

58. Roosenboom, P.; van der Kolk, T.; de Jong, A. What determines success in initial coin offerings? Ventur. Cap. 2020, 22, 161-183. [CrossRef]

59. Momtaz, P.P. Initial coin offerings, asymmetric information, and loyal CEOs. Small Bus. Econ. 2020, 1-23. [CrossRef]

60. Boreiko, D.; Risteski, D. Serial and large investors in initial coin offerings. Small Bus. Econ. 2020, 1-19. [CrossRef]

61. Benedetti, H.; Kostovetsky, L. Digital tulips? Returns to investors in initial coin offerings. J. Corp Financ. 2021, 61, 101786. [CrossRef]

62. Momtaz, P.P. The pricing and performance of cryptocurrency. Eur. J. Financ. 2019, 1-14. [CrossRef]

63. Chen, K. Information asymmetry in initial coin offerings (ICOs): Investigating the effects of multiple channel signals. Electron. Commer. Res. Appl. 2019, 36, 100858. [CrossRef]

64. Ittonen, K.; Vähämaa, E.; Vähämaa, S. Female auditors and accruals quality. Account. Horizons 2003, 27, 205-228. [CrossRef]

65. ACFE. Report to the Nations: 2020 Global Study on Occupational Fraud and Abuse; ACFE: Austin, TX, USA, 2020; Available online: https:/ / www.acfe.com/report-to-the-nations/2020/ (accessed on 1 December 2020). 
66. Beyer, S. Gender differences in the accuracy of self-evaluations of performance. J. Pers. Soc. Psychol. 1990, 59, 960-970. [CrossRef]

67. Barber, B.M.; Odean, T. Boys will be boys: Gender, overconfidence, and common stock investment. Q. J. Econ. 2001, 116, 261-292. [CrossRef]

68. Huang, J.; Kisgen, D.J. Gender and corporate Finance: Are male executives overconfident relative to female executives? J. Financ. Econ. 2013, 108, 822-839. [CrossRef]

69. Levi, M.; Li, K.; Zhang, F. Director gender and mergers and acquisitions. J. Corp. Financ. 2014, 28, 185-200. [CrossRef]

70. Silverman, I.W. Gender differences in delay of gratification: A meta-analysis. Sex Roles 2003, 49, 451-463. [CrossRef]

71. Brouthers, K.D.; Brouthers, L.E.; Werner, S. Influences on strategic decision-making in the Dutch financial services industry. J. Manag. 2000, 26, 863-883. [CrossRef]

72. Baskaran, T.; Bhalotra, S.R.; Min, B.K.; Uppal, Y. Women Legislators and Economic Performance. 2018. Available online: https: / / ssrn.com/abstract=3205883 (accessed on 1 December 2020).

73. Blau, P.M. Inequality and Heterogeneity; Free Press: New York, NY, USA, 1977.

74. Huang, W.; Meoli, M.; Vismara, S. The geography of initial coin offerings. Small Bus. Econ. 2020, 55, 77-102. [CrossRef]

75. Momtaz, P.P. Entrepreneurial finance and moral hazard: Evidence from token offerings. J. Bus. Ventur. 2020. [CrossRef]

76. Adams, P.R.; Frizzo-Barker, J.; Ackah, B.B.; Chow-White, P.A. Making space for women on the blockchain. In Blockchain and Web 3.0: Social, Economic, and Technological Challenges; Ragnedda, M., Destefanis, G., Eds.; Routledge: Abingdon, UK, 2019 ; pp. 1-18.

77. DuPont, Q. Cryptocurrencies and Blockchains; Society, D.M., Ed.; Polity Press: Cambridge, UK, 2019. 